\title{
ArcheoSciences
}

Revue d'archéométrie

33 (suppl.) | 2009

Mémoire du sol, espace des hommes

\section{Geophysical investigations in the vicinity of the Persepolis Royal Terrace (Fars province, Iran)}

Sébastien Gondet, Amine Dhemaied, Kourosh Mohammadkhani and Fayçal Rejiba

\section{(2) OpenEdition}

12 Journals

\section{Electronic version}

URL: https://journals.openedition.org/archeosciences/1307

DOI: $10.4000 /$ archeosciences. 1307

ISBN: 978-2-7535-1599-4

ISSN: $2104-3728$

Publisher

Presses universitaires de Rennes

\section{Printed version}

Date of publication: 30 October 2009

Number of pages: $69-72$

ISBN: 978-2-7535-0943-6

ISSN: 1960-1360

\section{Electronic reference}

Sébastien Gondet, Amine Dhemaied, Kourosh Mohammadkhani and Fayçal Rejiba, "Geophysical investigations in the vicinity of the Persepolis Royal Terrace (Fars province, Iran)", ArcheoSciences [Online], 33 (suppl.) | 2009, Online since 30 October 2011, connection on 01 February 2022. URL: http://journals.openedition.org/archeosciences/1307 ; DOI: https://doi.org/10.4000/archeosciences. 1307 


\title{
Geophysical investigations in the vicinity of the Persepolis Royal Terrace (Fars province, Iran)
}

\author{
Sébastien Gondet*, Amine Dhemaied**, \\ Kourosh Mohammadkhani* and Fayçal Rejiba **
}

Keywords: GPR, electrostatic, magnetic, Persepolis, survey.

The work presented here was conducted within the research program of the Iranian-French joint expedition in the Marvdasht Plain launched in 2005 with the support of the Iranian Centre of Archaeological Research, the Parsa Pasargadae Research Foundation and the French Foreign Office. This project aims to understand better the functioning of the Achaemenid capital, the so-called Parsa, of which only the Royal Quarter is actually known (the terrace and adjacent buildings to the south). The location, shape and extension of the city itself are still unknown (Boucharlat, 2003). The surrounding territory (the actual Marvdasht Plain) which fed the Royal residence has yet to be studied, keeping in mind information provided by textual sources, namely the Persepolis Fortification tablets, that the city was supplied by farms or towns located in the vicinity. This was the situation despite the various surveys carried out in the last 70 years. Our surveys focused more widely on remains from the first millennium BC, although they also recorded any kind of human activity from any period. The field walking archaeological survey paid particular attention to the piedmont areas which had been poorly surveyed in the past. Other implemented methods included topographic surveys with special attention to hydraulic works, geophysical surveys in the immediate surroundings of the terrace (GPR and electrostatic) and on the plain (magnetic), and finally aerial photographic remote sensing research for a better reading of the shape of sites and their integration into the environment (off-sites) ${ }^{1}$.

Since the beginning of our work around Persepolis, we have planned geophysical testing in the vicinity of the Royal Terrace. The goal of our research has always been to reconstruct the evolution of the Persepolis hinterland, a hinterland corresponding to the royal site's close surroundings, as well as to the more distant plain with high agricultural potential around it, hereafter referred to as the Marvdasht plain. In the first years we worked mainly quite far from the Persepolis archaeological site to get an insight into the impact left by a large capital on the surrounding plain. In 2008 we focused our efforts on a geophysical survey of the remains next to Persepolis. With respect to the nature of the studied areas and the archaeological questions that each of these pose, two types of complementary methods were used:

- Around the Royal Terrace, bistatic Ground Penetrating Radar (pulse EKKO $100225 \mathrm{MHz}$ antenna, Sensor and Software,) and electrostatic methods (MPU prototype device with two 0.5 and $1 \mathrm{~m}$ dipoles, see details in Panissod, 1998) since these allow investigation of hard surfaces (location on Fig. 1). This aspect is of particular importance as this area was largely built and asphalted some thirty years ago when an old tourist resort was constructed. The greater possible

* UMR 5133 Archéorient, CNRS, Université Lyon 2.

** UMR 7619 Sisyphe, CNRS, Université Paris 6.

1. The project has been presented at the previous 2007 ISAP conference in Nitra (Gondet, 2007). 


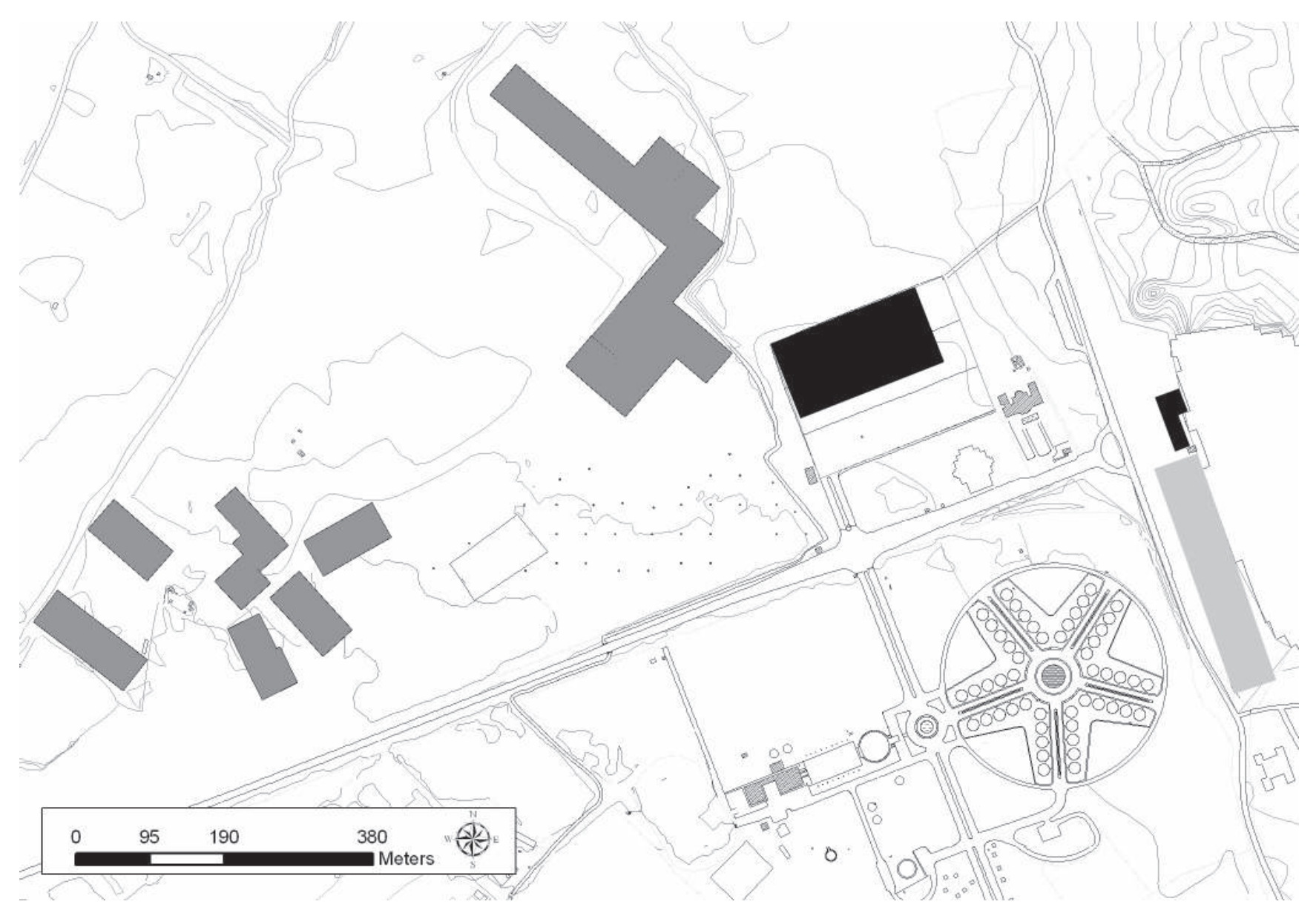

Figure 1: Location of surveyed areas (light grey GPR survey, dark grey magnetic survey, black electrostatic survey).

investigation depth of the GPR was also decisive as topsoil layers in the area have been largely disturbed by modern earthworks and by numerous limited excavations at the foot of the Terrace.

- In the cultivated fields close to the Royal Terrace and further, we used the magnetic method (G858 caesium gradiometer, Geometrics) as no metallic disturbances linked to modern installations were anticipated.

The results obtained by GPR and electrostatic methods have proven quite disappointing. No definite building layouts in the immediate vicinity of the Royal Terrace could be traced. The soil near the Terrace and under the West Parking is probably too disturbed, thus it is difficult to detect fine archaeological traces. All electrostatic and radar results confirm in fact the complex subsoil history which might have largely destroyed the archaeological remains or in which strong anomalies obscure possible archaeological structures. In addition to the radar method, the unexpected composition of the clayey soil (about $40 \mathrm{Ohm} . \mathrm{m}$ for the first meter obtained with electrostatic sounding) has induced a substantial attenuation of the received electromagnetic signal, particularly in the immediate vicinity of the terrace. Nevertheless, GPR and electrostatic maps do show some information concerning subsoil geology with archaeological consequences. Results of distinct electrostatic and GPR surveys have determined at least two areas of high archaeological interest: one in the Parking West (Fig. 2 B - electrostatic survey), indicated by high resistivity that cannot be explained by the recent earthworks; secondly, at the foot of the Royal Terrace (Fig. 2 C- GPR survey) with an area showing inverse E-shape. Outside this specific area, the results also show that it is quite unlikely to discover remains in the first meter (or meter and a half) of the soil layer (Fig. $2 \mathrm{~A}-$ electrostatic survey).

Magnetic data obtained in the fields near Persepolis offer a coherent image of former landscape organisation and appear to indicate a better state of preservation of the remains. Maps obtained show the presence of a fairly dense network 

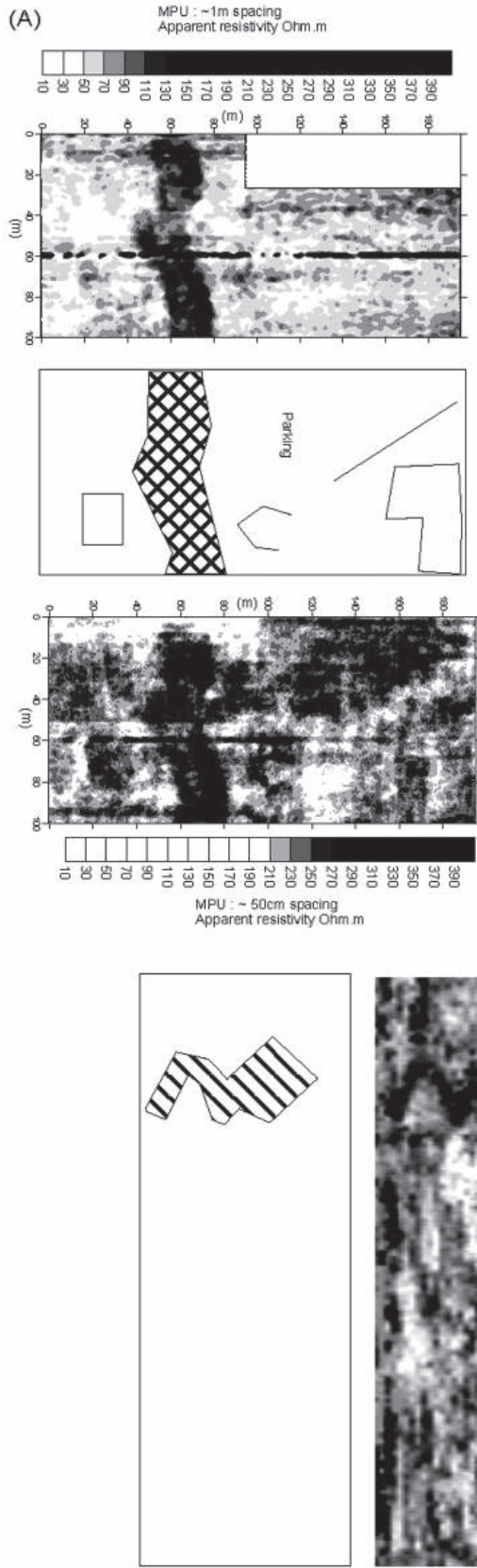

N

(B)

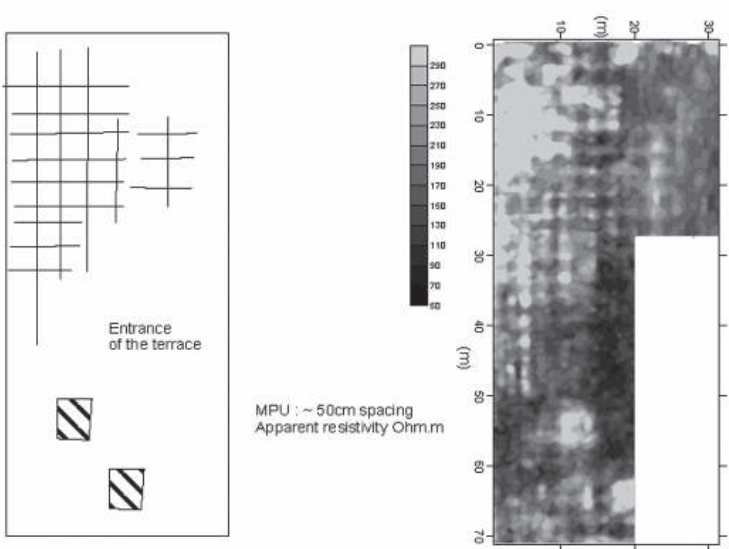

Figure 2: Mapping of apparent resistivity with electrostatic MPU quadripole (A) at the entrance to the Royal Terrace and (B) in a car park west of the Persepolis Royal Terrace (C) GPR raw signal converted to time slice map anomalies at an estimated depth of 0.5 and $1 \mathrm{~m}$ at the foot of the Persepolis Royal Terrace.

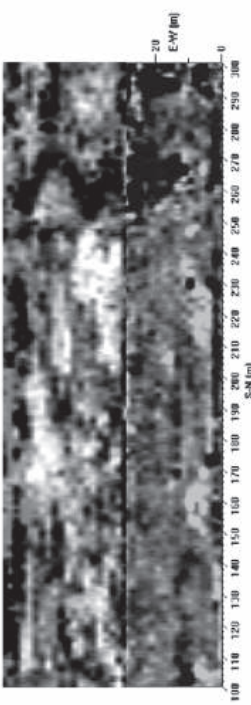

$\sim 50 \mathrm{~cm}$ depth
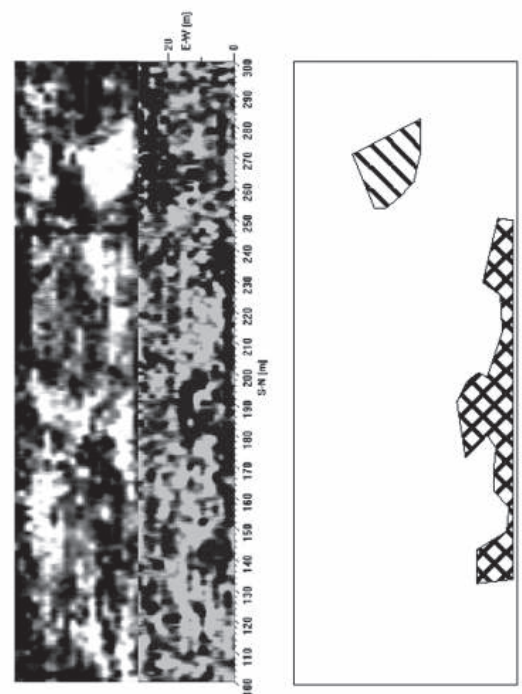

$\sim 1 \mathrm{~m}$ depth

of linear anomalies (Fig. 3). Together they make up a grid of irregular cells. However, we still see this grid as coherent because these lines respect a general alignment with two main perpendicular orientations. Of course the nature of these long linear anomalies should be tested, but it seems certain that they are related to the former landscape organisation. This initial interpretation is rather imprecise and it seems that it should be possible to provide a much better determination. We have therefore overlaid the magnetic maps with older aerial pictures taken before the reallotment of land. This work shows a different orientation of the field boundaries and ploughing traces compared to those on the magnetic maps, suggesting quite an old age for these magnetic anomalies. Secondly, we have also observed during the field-walking survey archaeological material, especially ceramic sherds, but also stone chips or fragments of stone vessels on the site surface. This material seems to correspond at least in part to Achaemenid times. Finally, on magnetic maps, 


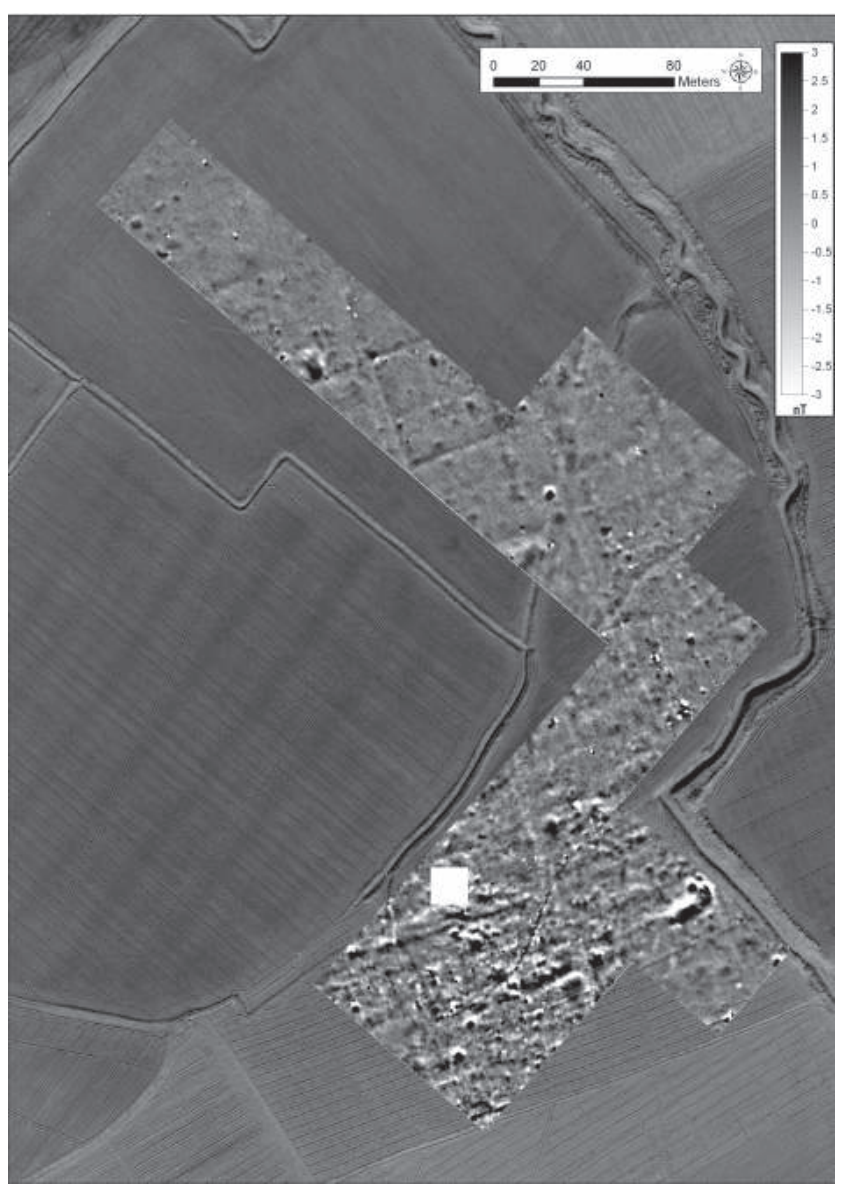

Figure 3: Magnetic gradient map of fields located northwest of the Persepolis Royal Terrace.

we have also observed some very limited traces of small rectangular anomalies, possibly related to buried remains of buildings. These shapes are integrated with the orientation of the general grid of long linear anomalies described above. In conclusion, this grid can be said to correspond to ancient landscape planning, possibly dating back to Achaemenid times and perhaps including both agricultural and garden areas within one considered plan.

\section{References}

Boucharlat, R., 2003. The Persepolis Area in the Achaemenid period: some reconsiderations. In N.F. Miller and K. Abdi (dir.). Yeki bud yeki nabud, Essays on the Archaeology of Iran in Honor of William M. Sumner, Monograph 28, Cotsen Institute of Archaeology, UCLA, 237-242.

GondeT, S., 2007. Multi-scaled approaches of a renewed survey program into the plain of Persépolis (Central Fars - Iran). Did everyone live in palaces during Achaemenid times?. Studijne zvesti Archeologickeho ustavu, SAV 41: 172-174.

Panissod, C., Dabas, M., Florsch, N., Hesse, A., Jolivet, A., TавваGH, A. and TAввAgh, J., 1998. Archaeological prospecting using electric and electrostatic mobile arrays, Archaeological Prospection, 5: 239-251. 